\title{
Habitat structure and the survival of juvenile scallops Pecten novaezelandiae: comparing predation in habitats with varying complexity
}

\author{
Sonia G. Talman ${ }^{1,2, *}$, Alf Norkko ${ }^{1}$, Simon F. Thrush ${ }^{1}$, Judi E. Hewitt ${ }^{1}$ \\ ${ }^{1}$ National Institute of Water and Atmospheric Research, PO Box 11-115, Hamilton, New Zealand \\ ${ }^{2}$ Present address: Marine and Freshwater Systems, Department of Primary Industries, PO Box 114, Queenscliff, \\ Victoria 3225, Australia
}

\begin{abstract}
Fishing disturbances that remove epifauna and other elements of benthic habitat structure have a secondary impact on the survival of juvenile Pecten novaezelandiae, the native New Zealand scallop. We investigated habitat structure and scallop predation rates in 4 soft-sediment habitats naturally utilised by $P$. novaezelandiae over multiple spatial scales. We found that habitats exposed to fishing disturbance had significantly fewer elements of benthic structure and that predation rates were significantly (up to $44 \%$ ) higher compared to unfished habitats. Habitat complexity primarily differed at the spatial scale of site, which corresponds to the scale of fishing disturbance. Scallop predation was negatively correlated with the number of habitat elements such as sponges, horse mussels and ascidians in the immediate area, and positively correlated with predator density. Another factor that affected juvenile scallop survival was ambient scallop density, with higher predation rates at the site where scallop numbers had been artificially enhanced. Although size-specific predation could not be formally tested in this study, it appeared that the predation rate was higher for larger scallops (mean size of $23 \mathrm{~cm}$ ) compared to smaller scallops (mean size of $16 \mathrm{~cm}$ ) in at least one of the sites but this requires further investigation. The results suggest that simplification of benthic systems by bottom-towed fishing activity degrades habitats and subsequently increases the vulnerability of juvenile scallops to predation. This may have important consequences for the sustainability of wild and enhanced scallop populations.
\end{abstract}

KEY WORDS: Habitat structure · Fishing impacts · Predation $\cdot$ Pecten novaezelandiae $\cdot$ Soft sediments $\cdot$ New Zealand

\section{INTRODUCTION}

Seafloor habitats naturally range from the simple, with little variability in sediments, topography and biogenic features, to the extremely complex, which may be characterised by the presence of emergent epifaunal species such as corals and sponges, and vegetation such as seagrass and macroalgae and variable substrates. The importance of architectural complexity or habitat 'structure' to associated fauna has long been recognised and is, in part, related to the availability of a variety of food resources, living spaces and refugia from competitors and unfavourable environmental conditions (e.g. Lough et al. 1989, Tupper \& Boutilier 1995). Habitat structure also provides refuge from predators, which is particularly important for the early life stages of bivalves and fish (Nelson \& Bonsdorff 1990, Persson \& Ekloev 1995, Rooker et al. 1998). Factors that affect juvenile survivorship also influence the size and distribution of adult populations (Tupper \& Boutilier 1995), so habitat complexity may have an important role in the sustainability of exploited populations.

One of the primary threats to habitat structure in the marine environment is bottom-towed fishing. Trawls 
and dredges which are dragged along the seabed remove and/or kill emergent epifauna, disturb sediments and infaunal species, and overturn physical features such as rocks and boulders, resulting in a smoother seafloor topography and homogenous surficial sediments (Mayer et al. 1991, Dayton et al. 1995, Auster et al. 1996, Jennings \& Kaiser 1998, Thrush et al. 1998, Watling \& Norse 1998, Auster \& Langton 1999). There are numerous examples of habitats that have been destroyed or severely degraded by fishing practices (e.g. Collie et al. 1997, Sainsbury et al. 1997, Thrush et al. 1998, Veale et al. 2000) and, as many structure-forming organisms are slow-growing with variable recruitment, recovery is likely to be slow (Watling \& Norse 1998, Thrush \& Dayton 2002). One of the impacts of this activity is a loss of refugia from predation, which can affect the composition and size of prey populations. For example, the survival of early benthic-phase fishes is adversely affected by the loss of benthic organisms offering emergent cover (Lough et al. 1989, Gotceitas \& Brown 1993, Tupper \& Boutilier 1995, Lindholm et al. 1999). Kaiser et al. (1999) found that, for flatfish populations, even slight changes in habitat topography favoured one species over another due to species-specific differences in predator avoidance behaviour.

To date, research has primarily focused on the link between habitat structure and the survival of juvenile fish. However, benthic structure may also influence the survival of other organisms, such as bivalves. Scallops, for example, are at their most vulnerable in the juvenile phase (Jensen \& Jensen 1985, Juanes 1992), and one of the main factors influencing juvenile survival is predation (e.g. Barbeau et al. 1994, 1996). Irlandi et al. $(1995,1999)$ demonstrated that predation on juvenile scallops is influenced by the size and spatial configuration of seagrass patches, while Pohle et al. (1991) showed that vertical attachment on seagrass functions as an effective predator-avoidance mechanism for juvenile scallops. To date, the relationship between scallop survival and habitat has only been examined within seagrass habitats (see also Peterson et al. 1989, Prescott 1990, Bologna \& Heck 1999), but structure in benthic habitats is comprised of many different elements and the abundance, spatial arrangement and interacting effects of any, or all, of these may affect the vulnerability of scallops to predation.

Our main objective was to identify the effect of habitat structure on juvenile scallop predation in habitats naturally utilised by Pecten novaezelandiae, the native commercial scallop of New Zealand. We measured habitat complexity, predator density and potential predation rate, defined as the rate at which the prey of interest would be consumed were they readily available to predators (Aronson 1989), in soft-sediment habitats in both the North and South Islands of New Zealand. We included 2 regions of New Zealand to cover a large geographical area and to assess the generality of the results. In addition, we specifically included habitats that were closed to bottom-towed

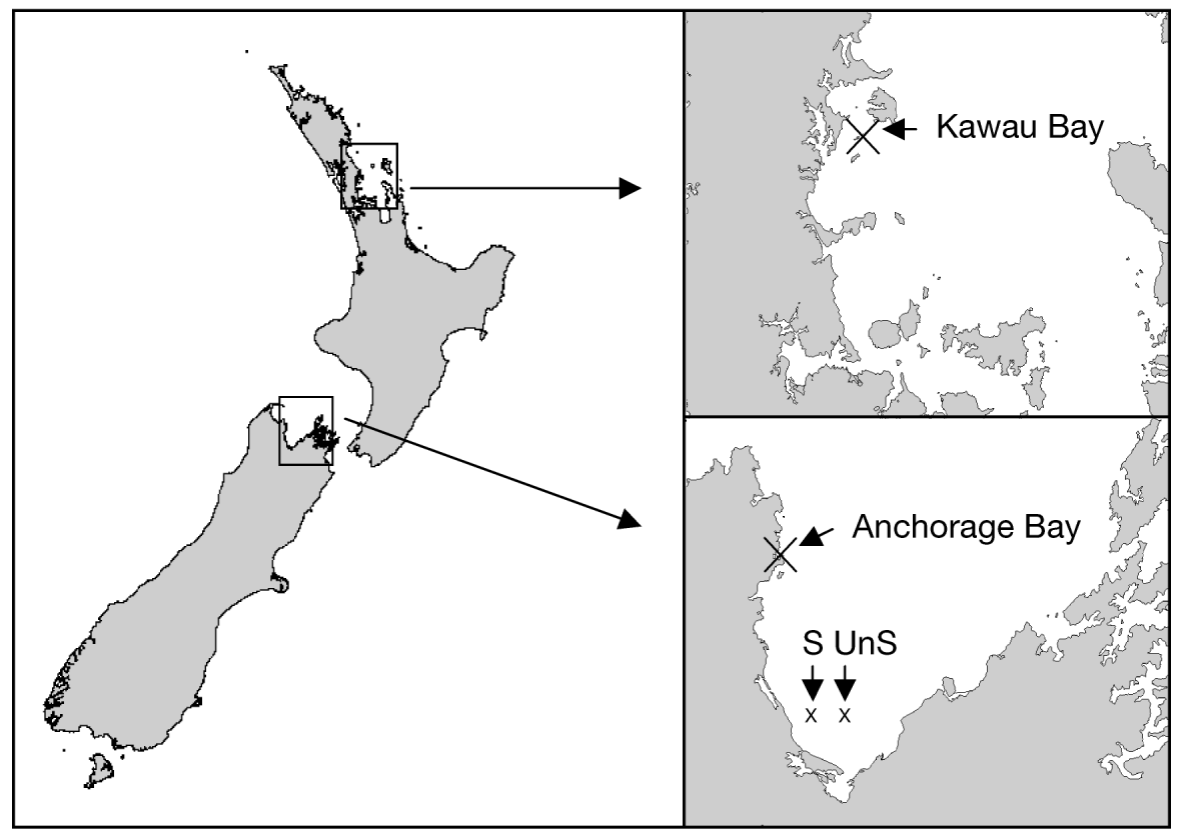

Fig. 1. Location of the 4 sites: Kawau Bay in the north, Anchorage Bay, and the seeded (S) and unseeded (UnS) sites in Tasman Bay in the south 
fishing methods and those with a history of fishing disturbance in order to assess the potential impact of fishing related changes to habitat structure, and the resulting impact of these changes on predation rates. We approached the measurement of habitat structure in a novel way by including all measurable aspects of the habitat, both biological and physical, at multiple scales. This meant that rather than merely contrasting 'simple' with 'highly structured' habitats, the full range and spatial variation of structural elements that comprise habitat structure were taken into account (e.g. Robbins \& Bell 1994, Thrush et al. 2001). In addition, we investigated the importance of other factors that potentially influence juvenile survival, such as ambient scallop density and scallop size (Barbeau \& Scheibling 1994, Barbeau et al. 1994, Nadeau \& Cliche 1998).

\section{MATERIALS AND METHODS}

Field experiments. We conducted field experiments to examine the effect of (1) habitat complexity, (2) predator density, (3) ambient scallop density and (4) scallop size on potential predation rates of juvenile scallops Pecten novaezelandiae. The experiments were conducted at 4 sites (approximately $100 \times 100 \mathrm{~m}$ ) at depths of approximately $10 \mathrm{~m}$ (Fig. 1). One site was near Motuketekete Island in Kawau Bay on the northeast coast of the North Island of New Zealand $\left(36^{\circ} 28.29^{\prime} \mathrm{S}, 174^{\circ} 48.36^{\prime} \mathrm{E}\right), 2$ sites were in Tasman Bay $\left(41^{\circ} 12.25^{\prime} \mathrm{S}, 173^{\circ} 10.25^{\prime} \mathrm{E}\right.$ and $41^{\circ} 11.75^{\prime} \mathrm{S}$, $\left.173^{\circ} 10.25^{\prime} \mathrm{E}\right)$ and 1 site was in Anchorage Bay $\left(40^{\circ} 57.06^{\prime} \mathrm{S}, 173^{\circ} 03.38^{\prime} \mathrm{E}\right)$. Both Tasman Bay and Anchorage Bay are on the north coast of the South Island of New Zealand. All 4 sites are primarily composed of soft-sediment habitats with varying sediment and biogenic characteristics. These sites were chosen to incorporate a range of geographical locations and different levels of disturbance by commercial fishing activity. Kawau Bay in the north and Anchorage Bay in the south are closed to commercial fishing, while Tasman Bay is the site of a scallop enhancement program and is dredged on a regular basis.

To assess the effect of ambient scallop density on scallop survival, densities were artificially manipulated at one of the Tasman Bay sites. This site was 'seeded' with juvenile scallops (approximately 10 to $15 \mathrm{~mm}$ shell width) by the Challenger Scallop Enhancement Company (CSEC). To seed the area, a large buoy was deployed and scallop spat were released in ever widening circles around the buoy. A second buoy was deployed to mark the edge of the seeded area. Approximately 1.18 million scallops were released in the seeded site $(100 \times 100 \mathrm{~m})$ over $3 \mathrm{~d}$ (February 24 to 26, 2001).
Within each of the 4 sites, 4 locations were haphazardly chosen to include the variety of habitats observed. In each of these locations, a $5 \mathrm{~m}$ length of galvanised chain (6.5 $\mathrm{mm}$ link painted matt black) was deployed. The chains were marked at $40 \mathrm{~cm}$ intervals to give a total of 12 'positions' per chain, with $10 \mathrm{~cm}$ of slack chain at either end. At the mid-point of each position, a cable tie $(100 \times 2.5 \mathrm{~mm})$ was attached to form a small loop. A single scallop was tethered to each cable tie on chains in 3 locations. The chain in the 4th location was used as a test for predator aggregation to chains without scallops. Thus the study was conducted over a series of spatial scales: position $(40 \times 80 \mathrm{~cm}$, see below), location $(480 \times 80 \mathrm{~cm})$ and site $(100 \times 100 \mathrm{~m})$ (Fig. 2).

Divers collected the juvenile scallops used in experiments in Kawau Bay from the surrounding area, while those used in the South Island sites were obtained from spat collectors maintained by CSEC. Scallops were held in $60 \mathrm{l}$ bins of aerated seawater overnight between tethering and deployment. To tether scallops, one end of a length of monofilament line $(15 \mathrm{lb} ; 7 \mathrm{~kg})$ was tied to a small length ( 3 to $5 \mathrm{~mm}$ ) of twine that was then glued to the upper valve of the scallop using Selleys ${ }^{\circledR}$ SupaGlue. The other end of the line was tied to a length of wire $(100 \times 0.7 \mathrm{~mm})$ that could then be twisted around the cable tie. Effective tether length was approximately 17 to $20 \mathrm{~cm}$.

To assess the effect of scallop size on scallop survival, 2 sizes, 'small' and 'large', were tethered in an alternate arrangement on each chain, starting with a small individual. Small and large scallops were $<20$ or $>25 \mathrm{~mm}$ shell width in Kawau Bay (actual mean \pm SE sizes of $21 \pm 3$ and $30 \pm 3 \mathrm{~mm}$, respectively) and $<20$ or $>20 \mathrm{~mm}$ in the southern sites (actual mean \pm SE sizes of $16 \pm 2$ and $23 \pm 2 \mathrm{~mm}$, respectively).

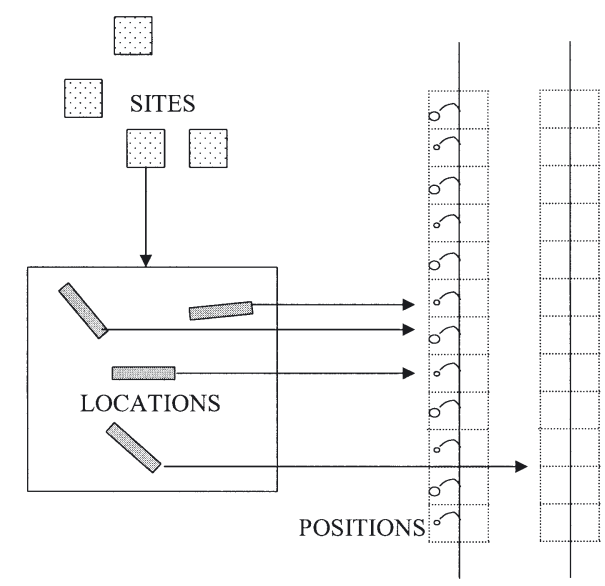

Fig. 2. Pecten novaezelandiae. Experimental design: 4 sites (approx. $100 \times 100 \mathrm{~m}), 4$ locations in each site $(480 \times 80 \mathrm{~cm})$, scallops tethered to 12 positions in 3 locations in each site $(40 \times 80 \mathrm{~cm})$ 
SCUBA divers tethered scallops to chains in Kawau Bay on February 20, in the 2 Tasman Bay sites on April 2 and in Anchorage Bay on April 6, 2001. Scallops were then checked on a daily basis for $3 \mathrm{~d}$ as well as $1 \mathrm{wk}$ after tethering. The status (alive or dead) of the scallop in each position was recorded, and dead individuals were measured and replaced with live ones. Due to bad weather, scallops were not checked on the first monitoring day at the 2 Tasman Bay sites, and due to logistical constraints, scallops were not checked after 1 wk at Anchorage Bay. However, the measure of mortality was the number of scallops found dead as a percentage of the number tethered in each position over the entire experiment, therefore missed monitoring days were taken into account.

Habitat data were obtained from video footage taken on the initial day when chains were set and scallops tethered. SCUBA divers collected footage from both sides of each chain using a digital video camera with the lens held perpendicular to the seafloor, at $50 \mathrm{~cm}$ above the seabed. During analysis of this footage, the markers that delineated each $40 \mathrm{~cm}$ length of chain were clearly visible on the screen, so that it was possible to mark out the same length in a horizontal direction. This meant that the area analysed for each position measured $40 \times 80 \mathrm{~cm}$ or $0.32 \mathrm{~m}^{2}$. The scallop in each position could swim to either side of the chain, to a distance of $20 \mathrm{~cm}$ (tether length). The various biological and physical features seen in each position were counted and measured. Then, for each position, the number of habitat elements, the area covered by biological features and the number of biological and physical features present was calculated (see Table 1). The number of habitat elements was a summation of all individual elements, e.g. actual number of scallops, mussels, etc. The area covered by biological features was a summation of values (each feature was given a value representing the area covered, i.e. $0=0 \%, 1=1$ to $25 \%, 2=26$ to $50 \%, 3=51$ to $75 \%, 4=76$ to $100 \%$ ). The number of biological and physical features was a count of how many of each type of feature was present. For example, if only horse mussels were found in a position, the number of biological features for that position would equal 1, even if there was more than 1 horse mussel present.

On the last monitoring day, sediment samples $(5 \mathrm{~cm}$ depth) were collected from each position and frozen until analysis. The amount of organic content in each sample was measured as the weight loss from ignition at $400^{\circ} \mathrm{C}$ for $6 \mathrm{~h}$ of a mixed sample that had been previously dried at $60^{\circ} \mathrm{C}$ for $48 \mathrm{~h}$.

Three measures of predator density were obtained. The first measure was obtained from video footage taken on the initial day and was a measure of predator density before predators had time to detect scallops and potentially aggregate. It also corresponded to habitat data, which was also obtained from video footage taken on the initial day. The second series of measurements were obtained from video footage taken 1, 2, 3 and $7 \mathrm{~d}$ after tethering to detect potential aggregation of predators. For both the first and second series of measurements, epibenthic predators (seastars, gastropods and crabs) in each position were counted.

Table 1. Categories of habitat structure. The number of habitat elements was a summation of all individual elements, e.g. actual number of scallops, mussels, etc. The area covered by biological features was a summation of values (each feature was given a value representing the area covered, i.e. $0=0 \%, 1=1$ to $25 \%, 2=26$ to $50 \%, 3=51$ to $75 \%, 4=76$ to $100 \%$ ). The number of different biological and physical features were counts of how many of each type of feature was present. For example, if only horse mussels were found in a position, the number of biological features for that position would equal 1, even if there was more than 1 horse mussel present

\begin{tabular}{|lccc|}
\hline $\begin{array}{l}\text { Number of } \\
\text { habitat elements }\end{array}$ & $\begin{array}{c}\text { Area covered by } \\
\text { biological features }\end{array}$ & $\begin{array}{c}\text { Number of different } \\
\text { biological features present }\end{array}$ & $\begin{array}{c}\text { Number of different } \\
\text { physical features present }\end{array}$ \\
\hline Scallops & Scallops & Scallops & Cobble \\
Horse mussels & Horse mussels & Horse mussels & Pebble \\
Sponges & Sponges & Sponges & Sand \\
Worm tubes & Worm tubes & Worm tubes & Shells \\
Holes/burrows & Algal mat & Holes/burrows & Shell hash \\
Ascidians & Hydroids & Hydroids & Diatom mat \\
Algal turf & Diatom mat & Ascidians & Algal turf \\
Sea cucumbers & Biodeposits & Algal mat & Biodeposits \\
Bivalves & & Sea cucumbers \\
Sea urchins & & Bivalves & Sea urchins \\
Hermit crabs & & Hermit crabs \\
& & & \\
& & & \\
\hline
\end{tabular}


The third measure of predator density included epibenthic and endobenthic predators that, due to small size, cryptic colouring or location, were not visible in the video footage. This was obtained on the final monitoring day. SCUBA divers placed quadrats measuring $40 \times 40 \mathrm{~cm}\left(0.16 \mathrm{~m}^{2}\right)$ on top of the chain in each position so that the chain ran through the middle of the quadrat. Within each quadrat, epibenthic predators were first counted and then endobenthic predators were extracted by raking through the surface sediment. Data on sediments and the density of endobenthic predators were only collected on the final day because both collection methods disturbed the habitat.

Statistical analyses. Similarities in habitat complexity between sites were investigated using multivariate techniques. The variables used in the analysis were: the number of habitat elements, the number of physical features, area covered by biological features and percent sediment organic content (Table 1). The number of biological features was not included in the analysis because this measure was not independent from the number of habitat elements. Because the data were a mixture of counts and a measurement of coverage by biological features, a Chord transformation on the biological data was used (see Legendre \& Gallagher 2001), followed by a principal component analysis (PCA).

Mortality data (arcsine transformed) were examined to determine whether there were any significant differences between sites (or between positions along the chains). An ANOVA model with 2 fixed factors (site and position), their interaction term and a random factor (location) nested within site was used. When a significant effect $(\mathrm{p}<0.05)$ was observed, multiple comparisons of means were performed using Scheffé's tests. For this ANOVA, position was recoded to 'end' (last 2 positions on each chain end), 'centre' (the 4 central positions) and 'in-between' (the remaining 2 positions either side of the central 4), i.e. 4 replicates per position code per chain. Position was recoded to reflect the possibility that predators might be attracted over small distances to either the chain and/or the scallops on the chain. Thus, the effect would be greatest in the 'centre' where there was the highest concentration of scallops, and this would lessen towards the ends.

The potential for both chains and scallops to act as attractors to predators was also investigated using differences between the initial predator density and the predator density measured after $2 \mathrm{~d}$. Densities were summed across the whole length of each chain and paired $t$-tests calculated for (a) the chains with no scallops and (b) the chains with scallops.

Scallop mortality was regressed against measures of habitat structure (number of habitat elements, area covered by biological features, number of biological and physical features and sediment organic content) and predator density (first measure obtained from video footage taken on initial day and third measure obtained from quadrats on final day) in each position. The second measure of predator density (obtained from video footage taken 1,2, 3 and $7 \mathrm{~d}$ after tethering) was not included as it was used to detect potential predator aggregation and was, essentially, a daily value of the first density measurement. The regression model was developed by backward selection of variables with p-values greater than 0.15 if removal did not markedly increase residual errors (Crawley 1993).

Patterns of size-dependent mortality were observed but not tested between sites due to differences in the size of 'small' and 'large' scallops between Kawau Bay and the southern sites.

\section{RESULTS}

\section{Habitat complexity}

Video footage showed that the sites closed to fishing (Kawau Bay and Anchorage Bay) were more complex in terms of habitat structure than those exposed to fishing impacts on a regular basis (2 sites in Tasman Bay, Fig. 3). At the Kawau and Anchorage Bay sites, there were large epifauna such as horse mussels, hydroids, ascidians and sponges, as well as worm tubes, biodeposits, burrows of various sizes, benthic algae and a variety of sedimentary features. This contrasts with the homogenous tracts of flattened sand that characterised the Tasman Bay sites. The seabed at these sites was primarily featureless, except for the presence of hermit crabs and shell hash, and of some medium-sized scallops at the unseeded site that were probably released there in the previous year. Consequently, the number of habitat elements, coverage by biological features and organic content of the sediment were higher at Kawau and Anchorage Bay than at the 2 Tasman Bay sites (Fig. 3). The number of physical features did not show the same overall pattern as the other habitat variables, however, as there was a similar amount of shell hash at all sites but there were more features (mainly pebbles, cobbles and intact shells) at Anchorage Bay (Fig. 3). These observations were supported by the PCA, which separated the habitat data into 3 groups: 1 consisting of positions at Kawau and Anchorage Bays, 1 of positions at the 2 Tasman Bay sites, and 1 of positions at the unseeded site in Tasman Bay where wild scallops were found (Fig. 4). Other than this group of positions, there was no separation of habitat data at the scale of position or location, although there was variation within sites. 


\section{Scallop mortality}

Dead scallops were recovered as undamaged clappers or were missing from the tether $(4 \%$ of total number tethered were missing), but none were crushed or chipped. For the purposes of this study, missing scal-
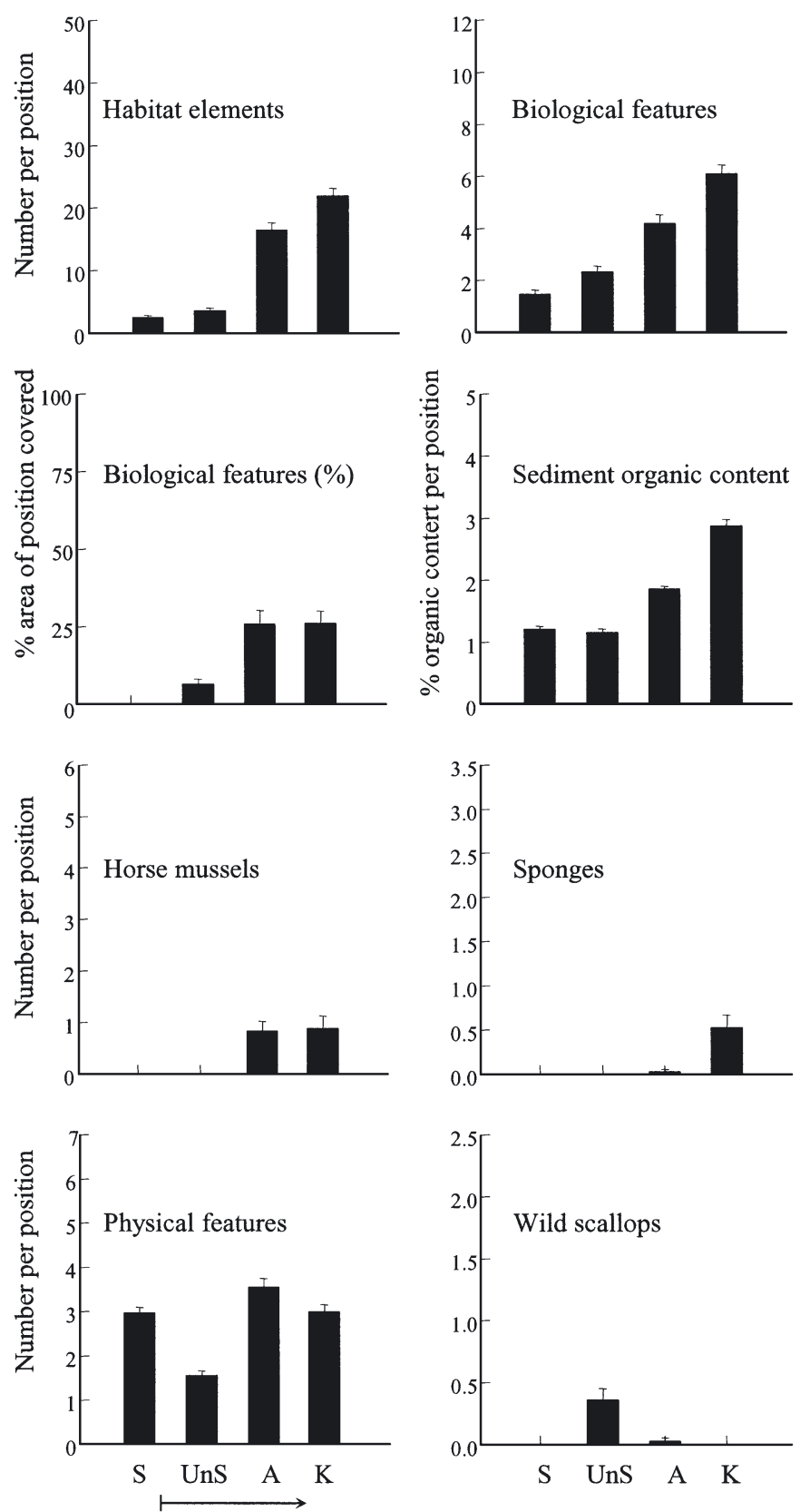

Increasing habitat complexity

Site

Decreasing disturbance history

Fig. 3. Habitat data per position $\left(0.32 \mathrm{~m}^{2}\right.$, mean $\left.\pm \mathrm{SE}\right)$ recorded at the study sites (S: seeded Tasman Bay; UnS: unseeded Tasman Bay; A: Anchorage Bay; K: Kawau Bay). Arrows indicate gradients of habitat complexity and disturbance history lops were presumed dead because tethered scallops that were held in aquaria for up to 1 wk remained firmly attached to their tethers. It is possible, however, that scallops came loose naturally in the field.

The ANOVA of scallop mortality showed a similar pattern as the habitat data, differing significantly

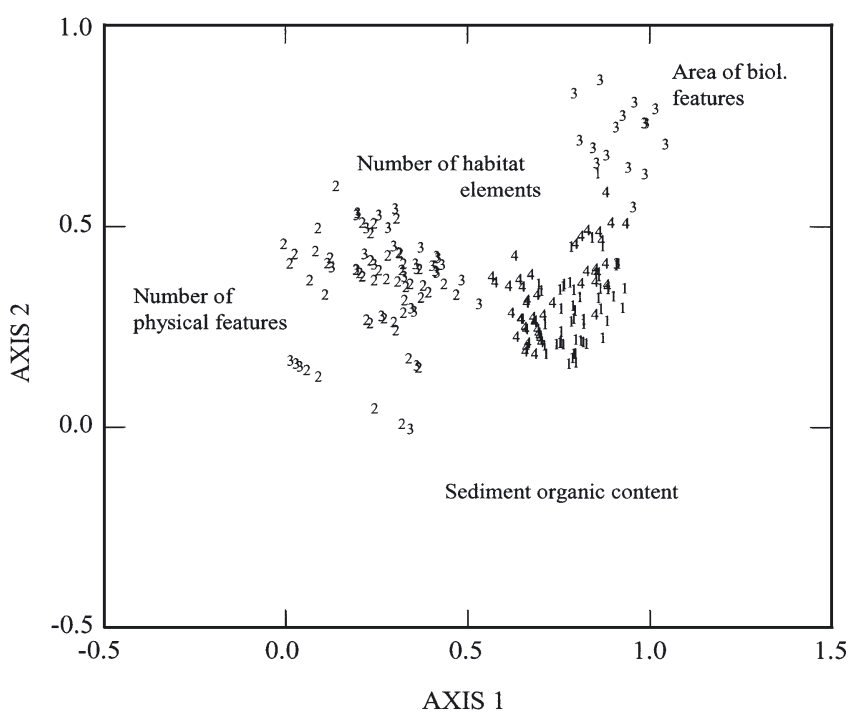

Fig. 4. Principal component analysis of habitat data: number of habitat elements, number of physical features, area covered by biological features (all Chord transformed) and percent sediment organic content (untransformed). Each number represents a position at Sites 1 (Kawau Bay), 2 (seeded Tasman Bay), 3 (unseeded Tasman Bay) and 4 (Anchorage Bay). Position of habitat variables was added to the figure using the scatterplot function in SYSTAT (co-ordinates were divided by 2 to achieve an appropriate scale)

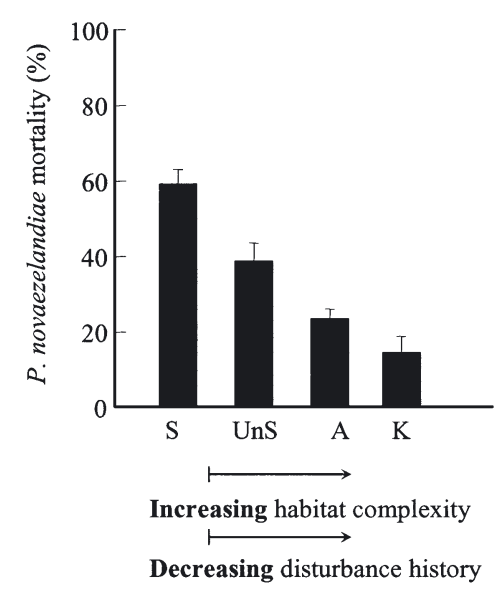

Fig. 5. Pecten novaezelandiae. Mortality (mean \pm SE) by site (S: seeded Tasman Bay; UnS: unseeded Tasman Bay; A: Anchorage Bay; K: Kawau Bay). Percentage found dead in each position over the course of the experiment (data were arcsine square-root transformed for analysis). Arrows indicate gradients of habitat complexity and disturbance history 
between sites but not between positions (Table 2, Fig. 5). The lowest mortality rates were found at the Kawau and Anchorage Bay sites, where there were the highest values of habitat structure, with average losses of 15 and $24 \%$ over $1 \mathrm{wk}$, respectively. These rates compared to average losses of 59 and $39 \%$ at the seeded and unseeded sites in Tasman Bay, respectively. While mortality rates in Kawau Bay were significantly lower than those recorded at both the Tasman Bay sites, mortality rates in Anchorage Bay were only lower than those recorded at the seeded site.

The regression analysis of scallop mortality showed that it was negatively related to the number of habitat elements (i.e. horse mussels, sponges, sea urchins, see Table 1) and organic content of the sediment (Table 3, Figs. 3 \& 5). Scallop mortality was positively correlated to the third measure, and (weakly) to the initial measure of predator density (Table 3 ). Predator density exhibited some differences between sites but these were not consistent across all 3 measurements (Fig. 6).

There was no aggregation of predators around the chains with $(t=-0.59, \mathrm{p}=$ 0.569 ) or without scallops ( $t=0.40, \mathrm{p}=$ 0.718 ).

Apart from the structure of the surrounding habitat and predator density, other factors that may influence juvenile scallop survival include the ambient density of juvenile scallops and scallop size. Scallop mortality was significantly higher at the seeded site, where there was a high density of juvenile scallops in the surrounding area, than at the unseeded site, where there was not (Table 2, Fig. 5). Although differences in mortality due to scallop size could not be formally tested in this study, Fig. 7 shows that the predation rates were higher for larger scallops (mean size of $23 \mathrm{~cm}$ ) compared to smaller scallops (mean size of $16 \mathrm{~cm}$ ) in Anchorage Bay.

\section{DISCUSSION}

\section{Habitat complexity}

Once ecosystems enter a fished state, diversity and production change; hence studies undertaken on these systems do not measure the impact of fishing. Ade-
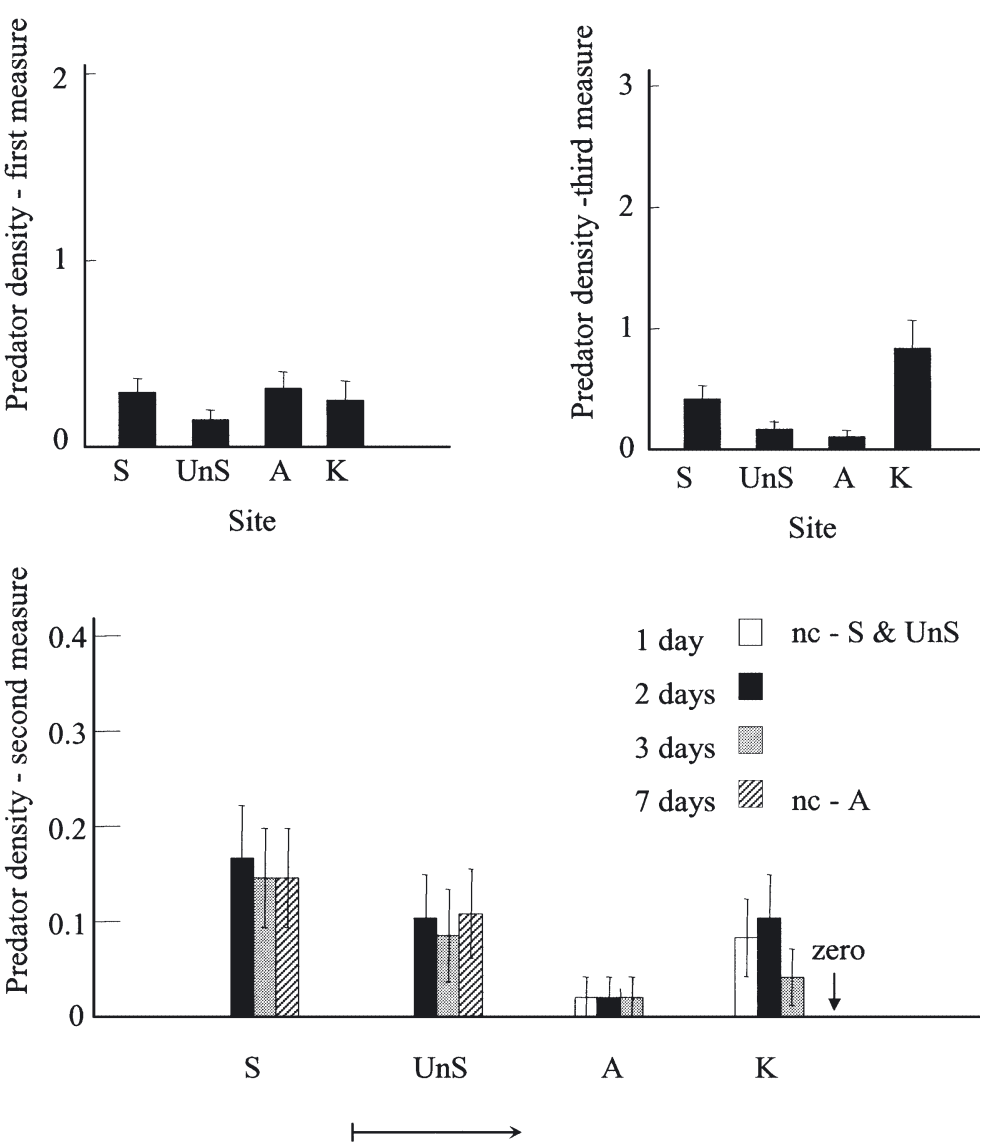

Increasing habitat complexity

Decreasing disturbance history

Fig. 6. Predator density (mean \pm SE) by site (S: seeded Tasman Bay; UnS: unseeded Tasman Bay; A: Anchorage Bay; K: Kawau Bay). First measure: number per position $\left(0.32 \mathrm{~m}^{2}\right)$, obtained from video footage on the initial tethering day. Second measure: number per position $\left(0.32 \mathrm{~m}^{2}\right)$, obtained from video footage taken 1, 2, 3 and $7 \mathrm{~d}$ after tethering (nc: data not collected). Third measure: number per position (quadrat: $0.16 \mathrm{~m}^{2}$ ), obtained from quadrats on final monitoring day

Table 2. Pecten novaezelandiae. ANOVA of mortality: percentage found dead in each position over the course of the experiment (arcsine square-root transformed). Value in bold: $\mathrm{p}<0.05$. Sites connected by lines are not significantly different from each other (Scheffé's test). No. of replicates $=4$. MS: mean square; S: seeded; UnS: unseeded

\begin{tabular}{|lrrrr|}
\hline Source of variation & df & MS & \multicolumn{1}{c|}{$F$} & $\mathrm{p}$ \\
\hline Site & 3 & 2.944 & 30.67 & $\mathbf{< 0 . 0 0 1}$ \\
Position & 2 & 0.099 & 0.76 & $>0.50$ \\
Site $\times$ Position & 6 & 0.016 & 0.12 & $>0.50$ \\
Location(Site) & 8 & 0.096 & 0.73 & $>0.50$ \\
Residual & 124 & 0.131 & & \\
Tasman(S) & Tasman(UnS) & \multicolumn{2}{c}{ Anchorage } & Kawau \\
& \multicolumn{5}{l}{} \\
\end{tabular}


Table 3. Pecten novaezelandiae. Regression analysis of mortality: percentage found dead in each position over the course of the experiment (arcsine square-root transformed) against habitat and predator data (first density measure is number per position, obtained from video footage on the initial tethering day, $\log _{10}[x+1]$-transformed; third density measure is number per position, obtained from quadrats on final monitoring day, $\log _{10}[x+1]$ transformed). MS: mean square. Values in bold: $\mathrm{p}<0.05$

\begin{tabular}{|c|c|c|c|c|c|c|}
\hline & $\mathrm{r}^{2}$ & df & MS & $F$ & Coefficient & $\mathrm{p}$ \\
\hline Regression & 0.036 & 4 & 2.320 & 19.197 & & 0.000 \\
\hline Residual & & 139 & 0.121 & & & \\
\hline \multicolumn{7}{|l|}{ Effect } \\
\hline Constant & & & & & & 0.000 \\
\hline Number of habitat elements (see Table 1) & & & & & -0.01 & 0.004 \\
\hline Number of predators (first density measure) & & & & & 0.07 & 0.172 \\
\hline Number of predators (third density measure) & & & & & 0.14 & 0.000 \\
\hline Sediment organic content \% & & & & & -4.58 & 0.002 \\
\hline
\end{tabular}

quate contrasts are important to fully understand how fishing modifies ecosystem structure and function. In this study, we were able to compare fished sites with unfished sites in the same geographical region, and our results show important differences in habitat structure between the two. The 2 sites that were closed to fishing were highly complex, whereas the 2 sites that were fished on a regular basis were primarily featureless. The low level of habitat structure at the fished sites in Tasman Bay is consistent with the effects of repeated dredging, which flattens the topography of the seabed and removes epibenthos (e.g. Auster \& Langton 1999). Although storm and wave disturbance can have a similar effect to fishing on the seafloor, and

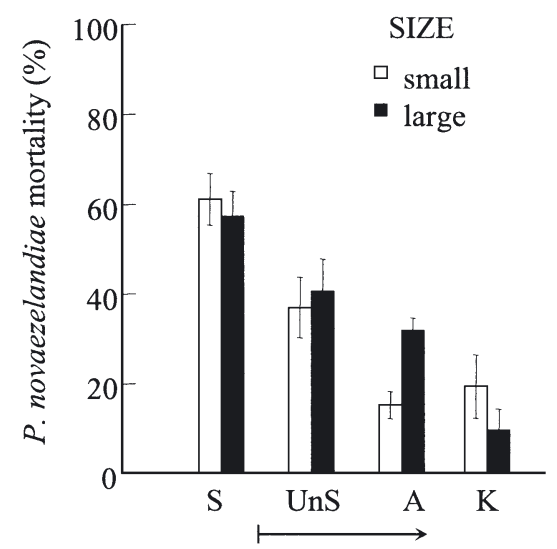

Increasing habitat complexity

Decreasing disturbance history

Fig. 7. Pecten novaezelandiae. Mortality (mean \pm SE) by size $(\mathrm{S}, \mathrm{UnS}$ and $\mathrm{A}$ : mean $\pm \mathrm{SE}$ of small and large is $16 \pm 2$ and $23 \pm$ $2 \mathrm{~mm}$, respectively. $\mathrm{K}$ : mean $\pm \mathrm{SE}$ of small and large is $21 \pm 3$ and $30 \pm 3 \mathrm{~mm}$, respectively) and site (S: seeded Tasman Bay; UnS: unseeded Tasman Bay; A: Anchorage Bay; K: Kawau Bay). Percentage found dead in each position over the course of the experiment (data were arcsine square-root transformed for analysis). Arrows indicate gradients of habitat complexity and disturbance history the Tasman Bay sites were more exposed to weather than the unfished sites, Bradstock \& Gordon (1983) reported extensive epifaunal growth in a nearby location with similar exposure to weather and swell. This indicates that the impact of dredging is primarily responsible for observed differences between Tasman Bay and the unfished sites. This is not the first observation of fishing impacts in the region. Bradstock \& Gordon (1983) noted that trawling had virtually destroyed beds of endemic 'coral-like' bryozoans in the Tasman Bay-Golden Bay area by the late 1970s. This has a significant impact on associated fish populations, and one of the less impacted beds was closed to power-fishing in 1980 in an effort to conserve the fishery.

\section{Scallop mortality}

The impact of fishing on habitat structure had a secondary effect on juvenile scallop survival. Potential predation rates were significantly lower at Kawau and Anchorage Bay, where there was high habitat complexity, compared to the 2 Tasman Bay sites, where habitats were comparatively simple. The effect of habitat on scallop predation was shown to be more important than geographical proximity and sampling time as rates were more similar between Kawau and Anchorage Bays, which are in different islands of New Zealand and were sampled in different months, than between Anchorage and the Tasman Bay sites, which are in relatively close proximity and were sampled in the same month (Fig. 1). Peterson et al. (1989) found that predation rates on adult scallops were lower in areas of comparatively high habitat complexity, but on a smaller scale and under conditions of natural habitat variability (seagrass patches versus patches of unvegetated sand). Although habitat variability in our study was related more to fishing intensity than to natural variability, a similar mechanism may underly the link between predation rates and habitat structure in both 
cases. Three-dimensional habitat structure is important in providing refuge from predators, particularly for juveniles, which are especially vulnerable (Jensen \& Jensen 1985, Juanes 1992). In our study, predation rates were lower where there was a greater number of individuals such as horse mussels Atrina zelandica, sponges and worm tubes surrounding the scallop. These features are emergent and, thus, provide physical refuge from visual predators. It is likely that these features also affect the success of predators that rely more on chemical cues for detecting prey, such as seastars and gastropods, as they modify benthic boundary flows that transport chemical cues (Zimmer et al. 1999). Elements of habitat structure may also act as obstacles for comparatively slow-moving predators (gastropods, seastars), thus limiting their mobility and, potentially, rates of prey capture.

From the undamaged state of dead scallops recovered in field experiments, and from field and laboratory observations (authors' unpubl. data), scallop predation in this study was primarily attributed to seastars and gastropods, although the species responsible probably differed between the northern and southern sites. Undamaged shells indicate seastar or gastropod predation because crabs, rays and predatory fish crush or chip the shell. Non-predatory death, followed by scavenging, may also result in undamaged shells, but we did not observe any scavenging nor any shells with fragments of flesh remaining. The most common predators found at the southern sites were the seastar Patiriella regularis and the gastropod Alcithoe arabica. Both species were observed feeding on juvenile scallops in the field, and $P$. regularis also fed on scallops in the laboratory. Other predators observed feeding on scallops at the southern sites were 2 seastar species Astrostole scabra and Sclerasterias mollis. The main predators at Kawau Bay probably differed from those at the southern sites, as P. regularis was not very common and $A$. arabica was absent. The small gastropod Cominella adspersa was the most common predator seen at Kawau Bay. Other predators observed at Kawau Bay included snapper, large rays, the seastar species Astropecten polyacanthus and Costinasterias calamaria, and the common octopus Octopus maorum.

Scallop predation was positively correlated with predator density, as determined from quadrats, and weakly with predator density, as determined from video footage. Intuitively, it is expected that predation will increase with the number of predators present, but predators can also exhibit a functional response. For example, Barbeau et al. (1994) demonstrated that a high rate of predation did not equate to high density of predators, but to a higher consumption rate per predator. Estimating predator density and relating it to predation rates obtained over a series of days can be problematic. Predatory species can be very mobile, so estimating density from a small area may not be appropriate. Similarly, foraging patterns are likely to vary temporally, so estimating density at one time, or even at one time per day, may not be optimal. The absence of a difference in predator numbers between initial conditions and after chains (and scallops) had been in place for $48 \mathrm{~h}$ indicates that predators were not aggregating to the chains themselves, nor to the tethered scallops.

Other factors that potentially affect scallop survival include ambient scallop density and scallop size. More scallops were consumed at the seeded site than at the unseeded site, indicating that ambient scallop density has an influence on juvenile scallop survival. This may be due to predators aggregating to an area of greater food availability or to a functional response of the predators that were present at the seeded site. For example, Barbeau et al. (1994) found that crab predation rate increased significantly with scallop density, but that crab density did not.

Scallop size may also affect survival due to differences in prey-vulnerability and active predator choice (Barbeau \& Scheibling 1994). In this study, it appeared that scallops of a mean size of $23 \mathrm{~cm}$ were consumed more than scallops of a mean size of $16 \mathrm{~cm}$ in at least one of the sites, but further investigation is required to confirm this pattern and the mechanism underlying it. Other studies have demonstrated that the seastar Asterias vulgaris consumes smaller scallops Placopecten magellanicus at a greater rate than larger scallops, but the preferred size range differs between the laboratory (5 to $8.5 \mathrm{~mm}$, Barbeau \& Scheibling 1994) and the field ( 5 to $15 \mathrm{~mm}$, Barbeau et al. 1994).

Scallop predation in this study was determined using tethered animals, and it is acknowledged that the process of tethering may artificially increase predation rates. However, the aim of the study was to compare predation between sites, so even if the rates we obtained were artificially high, it was still possible to compare these rates between sites. However, Peterson \& Black (1994) note that potential tethering artifacts do not remain constant across habitats if different consumers are present in different proportions in the habitats being compared and, in our study, different sets of predators were present in the northern and southern sites. Nevertheless, predation rates differed between the 3 southern sites where the same suite of predators was found, which may indicate that the impact of differential artifacts between sites was minimal. Despite potential artifacts, tethering experiments have been very useful in marine ecology, but the results must be interpreted cautiously (Aronson \& Heck 1995).

In conclusion, differences in the complexity of benthic habitats were only found at the scale of site, which 
corresponded to the scale of fishing disturbance. Our results show that broad-scale fishing disturbance reduced habitat complexity by removing epifauna and other structural features, and that a secondary effect of these changes was increased vulnerability of juvenile scallops to predation. Supporting evidence is that predation rates only differed at the scale of site, and that scallop mortality was negatively correlated with the number of structural elements providing refugia. This is the first empirical evidence that broad-scale differences in the structure of soft-sediment habitats have an important influence on predator-prey interactions.

Fishing-related changes to habitat that affect juvenile scallop survival may, in turn, adversely affect the sustainability of scallop fisheries because factors that influence juvenile survival also influence adult populations. There is the potential to use these results to promote the sustainability of the fishery, however, by acknowledging that habitat structure is important for juvenile scallop survival and fishing in a way that allows structure to re-establish (e.g. rotational fishing). The ecological effects of fishing need to be considered in management strategies, not only to conserve and protect marine environments, but also to ensure the sustainability of the fisheries that are intrinsically linked to them.

Acknowledgements. Thanks to the Challenger Scallop Enhancement Company for 'seeding' one of the Tasman Bay sites, providing advice, information and experimental scallops, and to R. Budd, G. Funnell, D. Schultz, C. Lundquist, K. May and S. Handley for assistance in the field. This research was supported by FRST C01x0007 and NIWA-NSOF PDA012 (postdoctoral fellowship to S.G.T.).

\section{LITERATURE CITED}

Aronson RB (1989) Brittlestar beds: low-predation anachronisms in the British Isles. Ecology 70:856-865

Aronson RB, Heck Jr KL (1995) Tethering experiments and hypothesis testing in ecology. Mar Ecol Prog Ser 121: 307-309

Auster PJ, Langton RW (1999) The effects of fishing on fish habitat. Am Fish Soc Symp 22:150-187

Auster PJ, Malatesta RJ, Langton RW, Watling L and 5 others (1996) The impacts of mobile fishing gear on seafloor habitats in the Gulf of Maine (northwest Atlantic): implications for conservation of fish populations. Rev Fish Sci 4: 185-202

Barbeau MA, Scheibling RE (1994) Behavioral mechanisms of prey size selection by sea stars (Asterias vulgaris Verrill) and crabs (Cancer irroratus Say) preying on juvenile sea scallops (Placopecten magellanicus (Gmelin)). J Exp Mar Biol Ecol 180:103-136

Barbeau MA, Scheibling RE, Hatcher BG, Taylor LH, Hennigar AW (1994) Survival analysis of tethered juvenile sea scallops Placopecten magellanicus in field experiments: effects of predators, scallop size and density, site and season. Mar Ecol Prog Ser 115:243-256
Barbeau MA, Hatcher BG, Scheibling RE, Hennigar AW, Taylor LH, Risk AC (1996) Dynamics of juvenile sea scallop (Placopecten magellanicus) and their predators in bottom seeding trails in Lunenburg Bay, Nova Scotia. Can J Aquat Sci 53:2494-2512

Bologna PAX, Heck KL Jr (1999) Differential predation and growth rates of bay scallops within a seagrass habitat. J Exp Mar Biol Ecol 239:299-314

Bradstock M, Gordon DP (1983) Coral-like bryozoan growths in Tasman Bay, and their protection to conserve commercial fish stocks. NZ J Mar Freshw Res 17:159-163

Collie JS, Escanero GA, Valentine PC (1997) Effects of bottom fishing on the benthic megafauna of Georges Bank. Mar Ecol Prog Ser 155:159-172

Crawley MJ (1993) GLIM for ecologists. Blackwell Scientific Publications, Oxford

Dayton PK, Thrush SF, Agardy TM, Hofman RJ (1995) Environmental effects of fishing. Aquat Conserv 5: 205-232

Gotceitas V, Brown JA (1993) Substrate selection by juvenile Atlantic cod (Gadus morhua): effects of predation risk. Oecologia 93:31-37

Irlandi EA, Ambrose WG Jr, Orlando BA (1995) Landscape ecology and the marine environment: how spatial configuration of seagrass habitat influences growth and survival of the bay scallop. Oikos 72:307-313

Irlandi EA, Orlando BA, Ambrose WG Jr (1999) Influence of seagrass habitat patch size on growth and survival of juvenile bay scallops, Argopecten irradians concentricus (Say). J Exp Mar Biol Ecol 235:21-43

Jennings S, Kaiser MJ (1998) The effects of fishing on marine ecosystems. Adv Mar Biol 34:203-314

Jensen KT, Jensen JN (1985) The importance of some epibenthic predators on the density of juvenile benthic macrofauna in the Danish Wadden Sea. J Exp Mar Biol Ecol 89:157-174

Juanes F (1992) Why do decapod crustaceans prefer smallsized molluscan prey? Mar Ecol Prog Ser 87:239-249

Kaiser MJ, Rogers SI, Ellis J (1999) Importance of benthic habitat complexity for demersal fish assemblages. In: Benaka L (ed) Essential fish habitat. Am Fish Soc Symp 22:212-223

Legendre P, Gallagher ED (2001) Ecologically meaningful transformations for ordination of species data. Oecologia 129:271-280

Lindholm JB, Auster PJ, Kaufman L (1999) Habitat-mediated survivorship of juvenile (0-year) Atlantic cod (Gadus morhua). Mar Ecol Prog Ser 180:247-255

Lough RG, Valentine PC, Potter DC, Auditore PJ, Bolz GR, Neilson JD, Perry RI (1989) Ecology and distribution of juvenile cod and haddock in relation to sediment type and bottom currents on eastern Georges Bank. Mar Ecol Prog Ser 56:1-12

Mayer LM, Schick DF, Findlay RH, Rice DL (1991) Effects of commercial dragging on sedimentary organic matter. Mar Environ Res 31:249-261

Nadeau M, Cliche G (1998) Predation of juvenile sea scallops (Placopecten magellanicus) by crabs (Cancer irroratus and Hyas sp.) and starfish (Asterias vulgaris, Leptasterias polaris, and Crossaster papposus). J Shellfish Res 17: 905-910

Nelson WG, Bonsdorff E (1990) Fish predation and habitat complexity: are complexity thresholds real? J Exp Mar Biol Ecol 141:183-194

Persson L, Ekloev P (1995) Prey refuges affecting interactions between piscivorous perch and juvenile perch and roach. Ecology 76:70-81 
Peterson CH, Black R (1994) An experimentalist's challenge: when artifacts of intervention interact with treatments. Mar Ecol Prog Ser 111:289-297

Peterson CH, Summerson HC, Fegley SR, Prescott RC (1989) Timing, intensity and sources of autumn mortality of adult bay scallops Argopecten irradians concentricus Say. J Exp Mar Biol Ecol 127:121-140

Pohle DG, Bricelj VM, Garcia-Esquivel Z (1991) The eelgrass canopy: an above-bottom refuge from benthic predators for juvenile bay scallops Argopecten irradians. Mar Ecol Prog Ser 74:47-59

Prescott RC (1990) Sources of predatory mortality in the bay scallop Argopecten irradians (Lamarck): interactions with seagrass and epibiotic coverage. J Exp Mar Biol Ecol 144: 63-83

Robbins BD, Bell SS (1994) Seagrass landscapes: a terrestrial approach to the marine subtidal environment. Trends Ecol Evol 9:301-304

Rooker JR, Holt GJ, Holt SA (1998) Vulnerability of newly settled red drum (Sciaenops ocellatus) to predatory fish: is early-life survival enhanced by seagrass meadows? Mar Biol 131:145-151

Sainsbury KJ, Campbell RA, Lindholm R, Whitelaw AW (1997) Experimental management of an Australian multispecies fishery: examining the possibility of trawl-induced habitat modification. In: Pikitch EK, Huppert DD, Sissen-

Editorial responsibility: Kenneth Heck (Contributing Editor), Dauphin Island, Alabama, USA wine MP (eds) Global trends: fisheries management. Am Fish Soc Symp 20:107-112

Thrush SF, Dayton PK (2002) Disturbance to marine benthic habitats by trawling and dredging: implications for marine biodiversity. Annu Rev Ecol Syst 33:449-473

Thrush SF, Hewitt JE, Cummings VJ, Dayton PK and 6 others (1998) Disturbance of the marine benthic habitat by commercial fishing: impacts at the scale of the fishery. Ecol Appl 8:866-879

Thrush SF, Hewitt JE, Funnell G, Cummings VJ, Ellis J, Schultz D, Talley D, Norkko A (2001) Fishing disturbance and marine biodiversity: the role of habitat structure in simple soft-sediment systems. Mar Ecol Prog Ser 221:255-264

Tupper M, Boutilier RG (1995) Effects of habitat on settlement, growth, and postsettlement survival of Atlantic cod (Gadus morhua). Can J Fish Aquat Sci 52:1834-1841

Veale LO, Hill AS, Hawkins SJ, Brand, AR (2000) Effects of long-term physical disturbance by commercial scallop fishing on subtidal epifaunal assemblages and habitats. Mar Biol 137:325-337

Watling L, Norse EA (1998) Disturbance of the seabed by mobile fishing gear: a comparison to forest clearcutting. Conserv Biol 12:1180-1197

Zimmer RK, Commins JE, Browne KA (1999) Regulatory effects of environmental chemical signals on search behavior and foraging success. Ecology 80:1432-1446

Submitted: June 30, 2002; Accepted: December 17, 2003

Proofs received from author(s): March 1, 2004 